\title{
Dynamic investigation of the effect of a relay ramp on simulated fluid flow: geocellular modelling of the Delicate Arch Ramp, Utah
}

\author{
A. Rotevatn ${ }^{1,2,3, *}$, J. Tveranger ${ }^{1}$, J. A. Howell ${ }^{1}$ and H. Fossen ${ }^{1,2}$ \\ ${ }^{1}$ Centre for Integrated Petroleum Research, University of Bergen, Allégaten 41, 5007 Bergen, Norway \\ ${ }^{2}$ Department of Earth Science, University of Bergen, Allégaten 41, 5007 Bergen, Norway \\ ${ }^{3}$ Present address: Rocksource ASA, Postboks 994 Sentrum, 5808 Bergen, Norway \\ *Corresponding author (e-mail: atle.rotevatn@rocksource.com)
}

\begin{abstract}
A fluid flow simulation study was performed to investigate potential contrasts in reservoir performance between models displaying a soft-linked relay ramp vs. models with a continuous fault. The relay ramp model is based on a well-exposed outcrop analogue - the Delicate Arch Ramp, Arches National Park, Utah. In outcrop, the relay ramp exhibits a pervasive system of cataclastic deformation bands, which were mapped and incorporated into the reservoir simulation models. Several models were simulated, using deformation-band permeability as the main variable tested. Results show that when compared to flow across continuous faults, the presence of soft-linked relay ramps enhances net flow across the fault zone in all tested scenarios. Comparing models with deformation bands to the model that includes the ramp but no deformation bands illustrates that, although having an impact on flow tortuosity and sweep efficiency, deformation bands must have a very low permeability and be numerous before having a negative impact on recovery. Deformation bands with midrange permeabilities were shown to have a positive effect on recovery in the relay models, as they increase flow tortuosity and enhance sweep, causing later water breakthrough and prolonging production. Using very low-permeable deformation bands in the same models caused extremely poor pressure communication between the fault-breached compartments, despite the geometric connectivity provided by the sub-continuous relay beds.
\end{abstract}

KEYWORDS: relay ramp, damage zone, fluid flow, flow simulation, reservoir modelling

\section{INTRODUCTION}

Fault populations evolve by growth and linkage of fault segments into longer, composite faults. In sedimentary sequences exposed to extension, such as in continental rifts, soft-linked relay ramps form as growing fault segments become overlapped along-strike, and strain is transferred from one segment to the other (e.g. Larsen 1988; Peacock \& Sanderson 1991). When the soft-linked relay ramp is eventually severed by through-going fault(s), a breached relay is formed (Childs et al. 1995).

It is known that soft-linked relay ramps may act as conduits for fluid flow across otherwise sealing fault systems (Hesthammer \& Fossen 1997; Manzocchi et al. 2004), although this has been quantified in only a limited number of papers (Bense \& Baalen 2004; Micarelli et al. 2006). Relay ramps may, therefore, exercise significant controls on fluid flow across faults in producing hydrocarbon reservoirs. However, some studies have documented that overlapping faults commonly are associated with the formation of a complex and anomalously wide fault damage zone (linking damage zone of Kim et al. 2004), which may well envelope the entire relay zone (Davatzes \& Aydin 2003; Kim et al. 2004; Fossen et al. 2005; Ciftci \& Bozkurt 2006; Rotevatn et al. 2007). Sub-seismic structural damage in the relay ramp may have profound effects on fluid

Petroleum Geoscience, Vol. 15 2009, pp. 45-58

DOI 10.1144/1354-079309-779 conductivity along the ramp (e.g. Walsh et al. 1998). Yet, the effects an enlarged damage zone may have on fluid flow along a relay ramp are poorly understood and have, so far, not been tested. This introduces uncertainty to the accepted paradigm that relay ramps are conduits for fluid flow. This paper aims to fill this gap in our understanding of relay ramps as conduits for fluid flow, and seeks to:

1. assess the effects of sub-seismic structural damage on fluid flow within a relay ramp by the application of a welldocumented field analogue (Rotevatn et al. 2007);

2. test these effects dynamically by the means of reservoir modelling and fluid flow simulation of the outcrop example;

3. assess the overall ability of relay ramps to act as cross-fault conduits for fluid flow based on results from the fluid flow simulation.

The analogue chosen in this study is a well-exposed relay ramp system in Arches National Park, Utah. This outcrop was chosen due to its setting in porous sandstones, analogous to many clastic reservoir rocks world-wide. We have previously published a structural study of this outcrop (Rotevatn et al. 2007), which forms the basis for the reservoir modelling and fluid flow simulation undertaken in the current study. First, however, due to the relay ramp's setting in porous siliciclastics, 

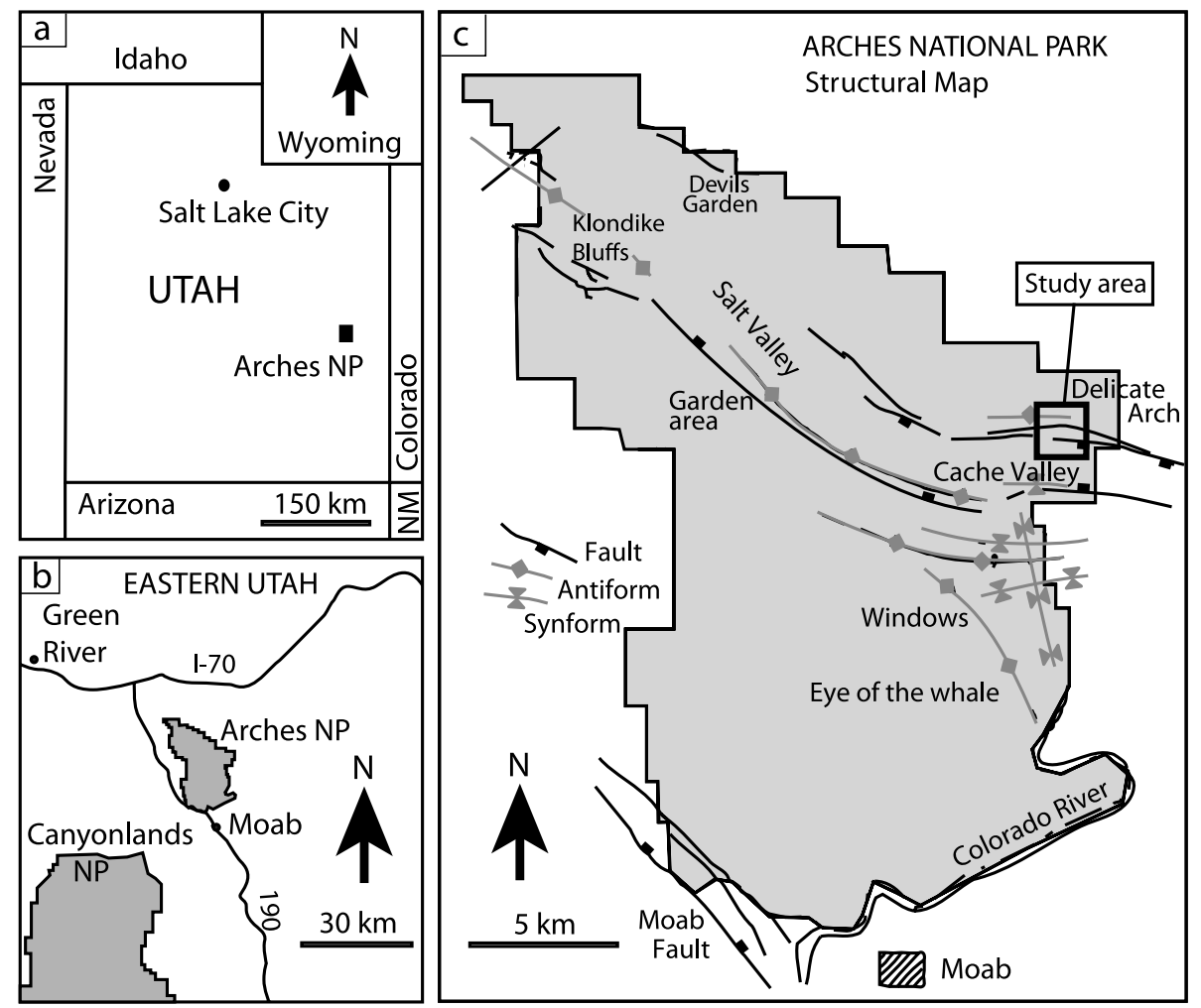

Fig. 1. Maps of (a) Utah and (b) Eastern Utah, showing the location of Arches National Park. (c) Structural map of Arches National Park based on Antonellini et al. (1994). The location of the study area in Cache Valley is indicated. an introduction to processes of faulting in such rocks is appropriate.

\section{FAULTING IN POROUS CLASTIC ROCKS}

Processes of deformation in porous clastic rocks are distinctly different from those of non-porous rocks. The presence of pore space permits certain deformation mechanisms to take place. First, pore space facilitates grain reorganization, repacking and - commonly, but not necessarily - compaction, with resulting changes in porosity. Secondly, grain contacts become stress focal points that promote grain fracturing and cataclasis under greater applied stress. The resulting strain localization features are known as 'deformation bands' (Aydin 1978), tabular-planar mm-thick 'shear bands' along which $\mathrm{mm}$ - to $\mathrm{cm}$-scale displacements take place. More rarely, 'compaction and dilation bands' occur, where shear is absent or negligible (Mollema \& Antonellini 1996; Du Bernard et al. 2002).

Classified by micro-structural deformation mechanism, two main types of deformation bands exist, 'disaggregation bands' and 'cataclastic bands' (Fossen et al. 2007). Disaggregation bands are characterized by reorganization of grains and commonly feature some compaction and reduced porosity in the band (Antonellini et al. 1994). A sub-type of disaggregation bands may form, where phyllosilicate minerals $(>15 \%)$ are present in the sand; these are referred to as 'phyllosilicate bands' (framework phyllosilicate bands of Knipe 1997). Cataclastic bands comprise a central core featuring grain crushing and pore collapse, encapsulated in a zone of grain compaction (Aydin 1978; Aydin \& Johnson 1983). Generally, cataclastic bands form at greater burial depths $(>1 \mathrm{~km}$ depth, Antonellini et al. 1994) than disaggregation bands, which are particularly common in loose or poorly consolidated sands (Mandl et al. 1977; Du Bernard et al. 2002; Bense et al. 2003). Exceptions exist, however, and cataclastic bands formed in unconsolidated sand at near-surface depths have been reported (e.g. Cashman \& Cashman 2000).
Fault formation in porous sandstones largely follows a three-stage pattern (Aydin \& Johnson 1978). Initially, individual deformation bands form when the host rock is subjected to tectonic stress. Subsequently, more deformation bands form and amalgamate to deformation band cluster zones. At some point, a slip plane forms within the cluster zone, and a fault, in the more conventional understanding of the term, forms. This process of fault formation has been corroborated by a number of field-based studies (e.g. Antonellini \& Aydin 1995; Fossen \& Hesthammer 1998; Shipton \& Cowie 2003) and has, to some extent, been reproduced in the laboratory (Mair et al. 2000; Lothe et al. 2002).

The petrophysical properties of deformation bands have been the focus of numerous studies (e.g. Antonellini \& Aydin 1994). In addition to the changes in porosity described above, permeability may be affected significantly by deformation band formation. Whereas disaggregation bands (except phyllosilicate bands) feature little or no permeability contrast relative to the host rock (Fisher \& Knipe 2001), cataclastic bands and phyllosilicate framework bands may, in extreme cases, exhibit a bulk permeability reduction of up to six orders of magnitude relative to the surrounding matrix (e.g. Underhill \& Woodcock 1987; Antonellini \& Aydin 1994; Fisher \& Knipe 2001; Shipton et al. 2002).

\section{GEOLOGICAL FRAMEWORK}

The Delicate Arch Ramp (Rotevatn et al. 2007) is located in the Cache Valley, Arches National Park, Utah, as part of a rollover structure situated in the hanging wall of a major E-W-trending, north-dipping normal fault (Fig. 1). In general, this fault system follows the collapsed crest of the Salt Valley Anticline (Fig. 1c), which formed as a response to up-doming and subsequent collapse of the subsurface evaporites of the Pennsylvanian Paradox Formation. The Delicate Arch Ramp is constrained by two antithetic (relative to the major fault in the south) normal faults (Fig. 2a). 

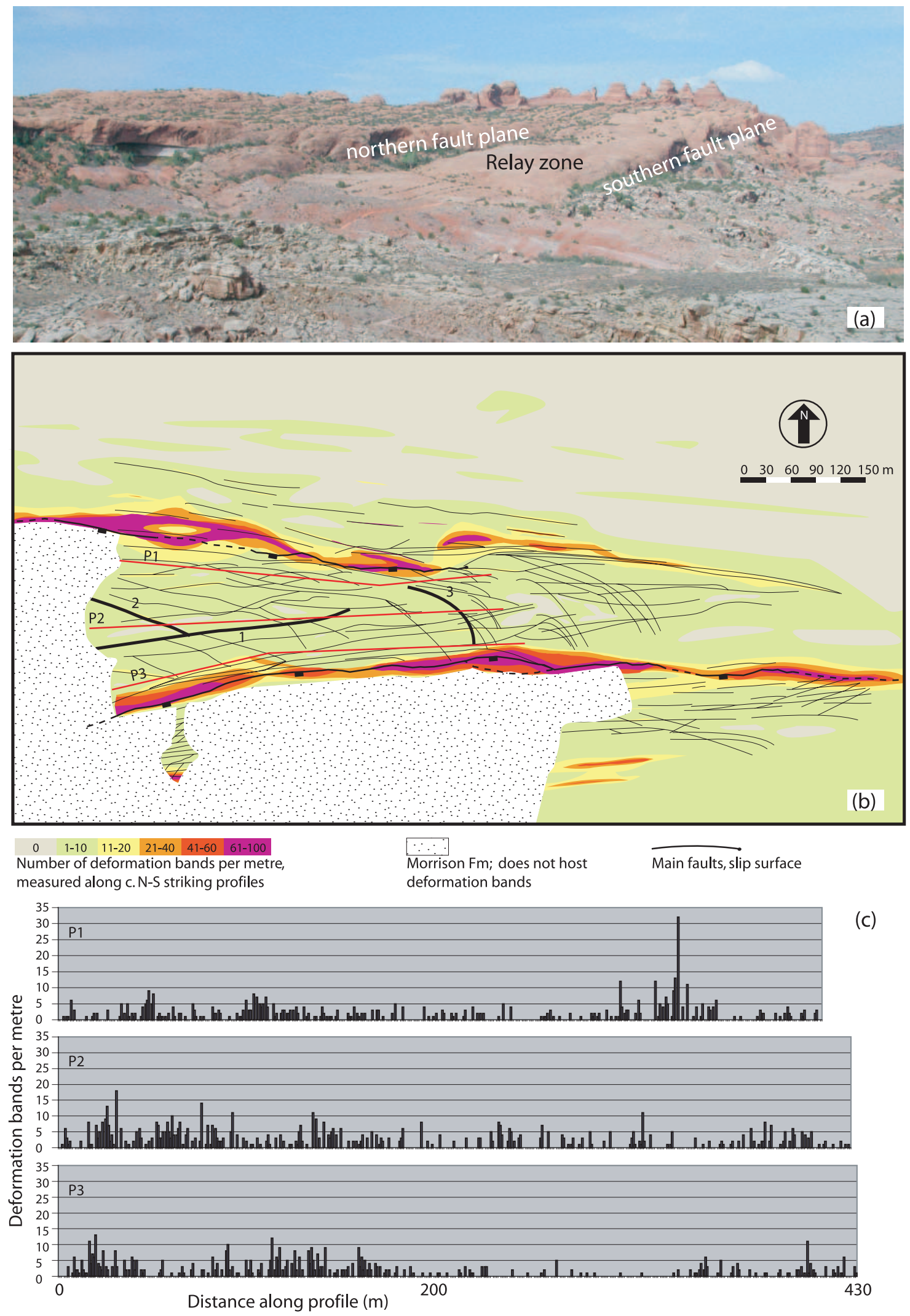

Fig. 2. (a) Photo of the Delicate Arch ramp. The fault planes of the bounding faults are exposed in the cliff walls adjacent to the ramp. (b) Structural trend and intensity map of the Delicate Arch ramp, illustrating the orientation and frequency of deformation bands. Deformation band frequency is represented by colour contours, based on the number of deformation bands per metre recorded along N-S profiles with a profile spacing of $40 \mathrm{~m}$. The resolution of the structures recorded in the profiles is $2 \mathrm{~mm}$ thickness. The structures drawn on the map record significant single cataclastic deformation bands ( $>5 \mathrm{~mm}$ thickness) and amalgamated multiple deformation bands, indicating the dominant orientations of deformation bands associated with the ramp. Examples of the three main orientations of bands are indicated with bold lines: (1) ramp-parallel bands, (2) ramp-diagonal bands and (3) curved bands. (c) W-E deformation band frequency profiles recorded along the relay ramp. The resolution of the structures recorded in the profiles is $2 \mathrm{~mm}$ thickness. The location of profiles P1, P2 and P3 are indicated in (b). 


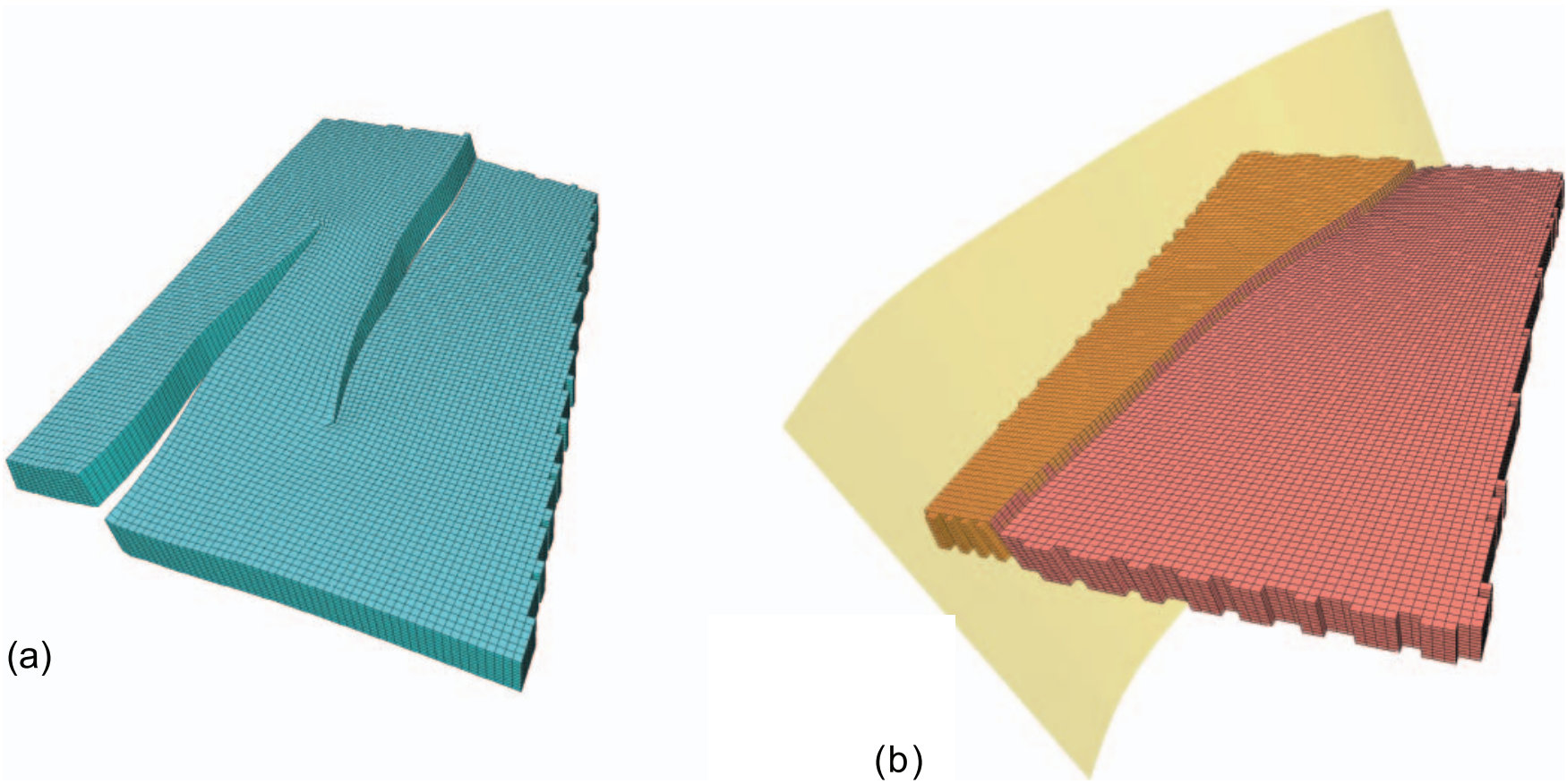

Fig. 3. The modelling grids built and used in the flow simulations. (a) The grid representing the studied field case at the Delicate Arch Ramp (relay grid). (b) Single fault grid. This grid was built with a single continuous fault for comparison with the relay models in the flow simulations.

The outcrop consists of a $c .80 \mathrm{~m}$ succession of the aeolian Moab (top $15 \mathrm{~m}$ ) and Slickrock (lower $65 \mathrm{~m}$ ) members, belonging to the Curtis and Entrada formations, respectively, of the Jurassic San Rafael Group (Doelling 2001). The Moab and Slickrock members feature a succession of massive, 4-20 m thick mature, aeolian dune units interbedded with 1-7 m thick, fine-grained heterolithic interdune units.

Previous studies of this area include the seminal works by Antonellini \& Aydin (1994; Antonellini \& Aydin 1995), who focused on the deformation of the sandstones in the area and its effect on fluid flow. The Delicate Arch Ramp per se was mapped, but was not a main subject of their studies. Other studies in the area include microstructural studies of deformation bands (Antonellini et al. 1994), studies of local and regional fracture patterns (Cruikshank \& Aydin 1995; Kattenhorn et al. 2000; Davatzes \& Aydin 2003) and a numerical study of pressure drawdown in faulted sandstone reservoirs (Matthäi et al. 1998).

Scan-line-based mapping of the Delicate Arch Ramp (Rotevatn et al. 2007) has previously revealed that the relay zone is affected by extensive networks of cataclastic deformation bands (Fig. 2b). Three main orientations of bands were identified: (1) ramp-parallel bands; (2) ramp-diagonal bands; and (3) curved bands (Fig. 2b). Deformation bands of these three orientations cross-cut and intersect, forming a highly complex network. The map presented by Rotevatn et al. (2007) has subsequently been supplemented by three more E-W scan lines (Fig. 2c).

\section{GEOLOGICAL MODELLING}

It has been suggested previously (Rotevatn $e t$ al. 2007) that the deformation band network in the Delicate Arch Ramp may have a negative effect on flow through the relay ramp. This work investigates the validity of this assumption by incorporating the outcrop observations in a fluid flow model and testing reservoir performance for a number of different scenarios. Roxar Software Solution's reservoir modelling suite Irap RMS 8.0 was used in this study.

\section{Data input}

The structural data that form the basis for model generation were collected using basic mapping techniques in the field. Faults and deformation bands were mapped on a 1:2150 enlargement of a high-resolution aerial photograph from the US Department of Agriculture. GPS was used for positioning in the global grid. The mapping of deformation bands was done in two ways: (1) discrete deformation bands were mapped on aerial photos. Only the most significant amalgamated bands/ clusters in terms of thickness $(>5 \mathrm{~mm})$ were mapped. These reflect the main orientations of structures on the ramp. (2) Deformation band frequency profiles were recorded along $\mathrm{N}-\mathrm{S}$ and E-W-orientated scan lines. The resolution of structures recorded along the scan lines is $c .2 \mathrm{~mm}$ (thickness of deformation bands as measured in the field). The collected structural data are shown graphically in Figures $2 \mathrm{~b}$ and $\mathrm{c}$ and are described in detail in Rotevatn et al. (2007). These data were digitized and converted to point data for use in the reservoir model, following methods described below.

\section{Model framework and grid}

The top of the reservoir model is initially defined by a horizontal surface. The base is defined by a second horizontal surface $50 \mathrm{~m}$ down from the first $(50 \mathrm{~m}$ model thickness, as opposed to the $80 \mathrm{~m}$ total thickness exposed at the outcrop, is used to reduce the total number of cells in the model). The faults, constraining the Delicate Arch Ramp, were digitized and incorporated into the model, and the top and base horizons adjusted to the faults, according to the recorded displacement. The resulting framework mimics the large-scale geometry of the ramp if it had been situated in the subsurface.

The model is relatively small $(c .1080 \times 680 \times 50 \mathrm{~m})$, which allows the use of a fairly detailed grid. The grid comprises $108 \times 68 \times 10$ cells, yielding a total number of 73440 cells (Fig $3 \mathrm{a})$. The low number of cells makes upscaling prior to flowsimulation redundant. The average cell size of the grid is $10 \times 10 \times 5 \mathrm{~m}$. As the grid should ideally be parallel to the main 
geological heterogeneity, the grid was rotated to conform to the orientation of the main faults (Fig. 3a). The faults were also used as guidelines to further optimize the grid, a side effect of which is that dimensions of individual grid cells may vary slightly to adapt.

For comparison with the relay ramp model, a second model with identical dimensions and grid cell configuration was also generated. This second model lacks the ramp but features a single through-going fault with a displacement of $40 \mathrm{~m}$ (Fig. 3b).

\section{Host-rock properties}

As the main objective of this study was to investigate the effects of the ramp and the damage zone of deformation bands on fluid flow, measures were taken to isolate these effects. Thus, in order to avoid interference of depositional heterogeneities in the results, reservoir sedimentology was modelled as a homogeneous sandbox in all cases. Petrophysical properties of the host rock are based on measurements presented in Antonellini \& Aydin (1994) and are kept constant throughout the model volume: porosity $28 \%$, horizontal permeability $1000 \mathrm{mD}$ and vertical permeability of $100 \mathrm{mD}$.

\section{Modelling deformation bands}

The main technical challenge of the current study is the incorporation of the damage zone, which consists of a multitude of millimetre-scale deformation bands, in the model. Deformation bands are far too small and numerous to be resolvable in the reservoir modelling grid. Even at a high grid resolution, such as here, $10 \times 10 \times 5 \mathrm{~m}$ grid cells are several orders of magnitude too large to discretely represent the mapped deformation band network (Fig. 2b). Thus, an implicit representation was applied.

The mapped frequency distribution of deformation bands was contoured based on a subdivision into six frequency classes (Fig. $4 \mathrm{a}$ and $2 \mathrm{~b}$ ). Contours were extrapolated in the areas where the overlying Morrison Formation covers the Moab Member. The six contours were digitized and imported into Irap RMS 8.0 (Fig. 4b) and used to generate a trend map. The trend map was converted to a $3 \mathrm{D}$ trend parameter by assuming all deformation bands to be sub-vertical and extrapolating trend map values vertically downwards through the reservoir interval (Fig. 4c). Each cell of the 3D trend parameter was thus assigned a value from 1-6 based on the mapped deformation band frequency.

As pointed out above, deformation bands may feature permeabilities several orders of magnitude lower than the surrounding host rock. The effective permeability of each cell is, therefore, tied to the frequency of deformation bands in that cell, as indicated by the 3D trend parameter (Fig. 4c). This parameter can, therefore, be used to estimate the effective permeability for each cell.

\section{Computing grid cell permeabilities}

The present study focuses on how the damage zone, in terms of permeability changes caused by deformation bands, affects fluid flow. Capillary effects as well as the effects of porosity reduction are not considered here. As deformation bands are modelled here as vertical, alterations in vertical permeability can be ignored since there is no way for fluids to flow around permeability barriers that are vertically continuous through a reservoir interval with sealed boundary conditions. Thus, for each cell, only permeability modifications in the $\mathrm{x}$ - and $\mathrm{y}$ directions (perm_x and perm_y) were considered. The 3D trend parameter is based on the contour map (Fig. 2b) which

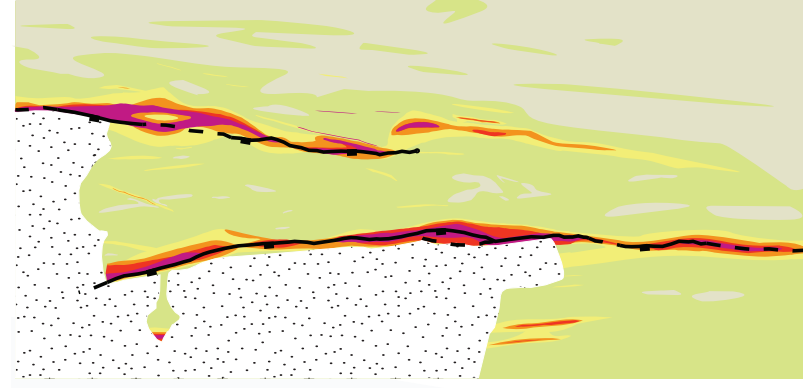

(a)
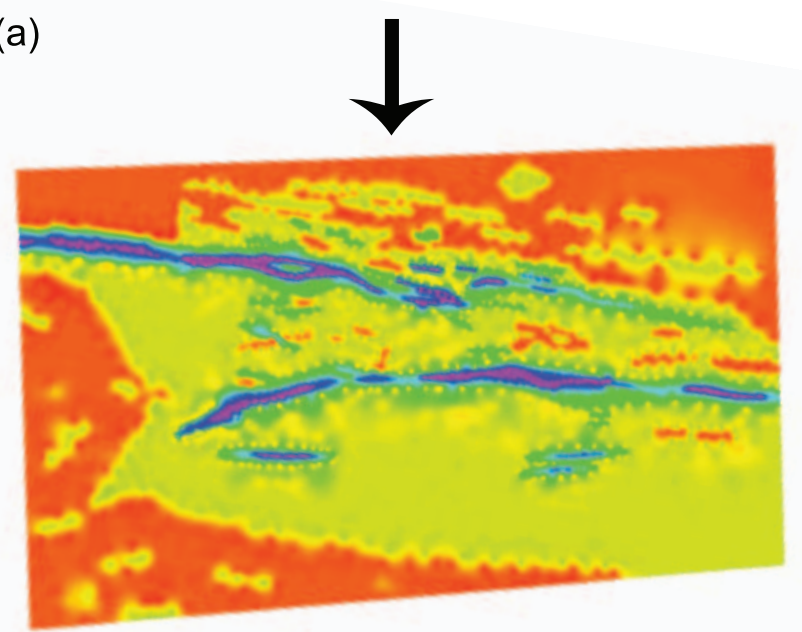

(b)
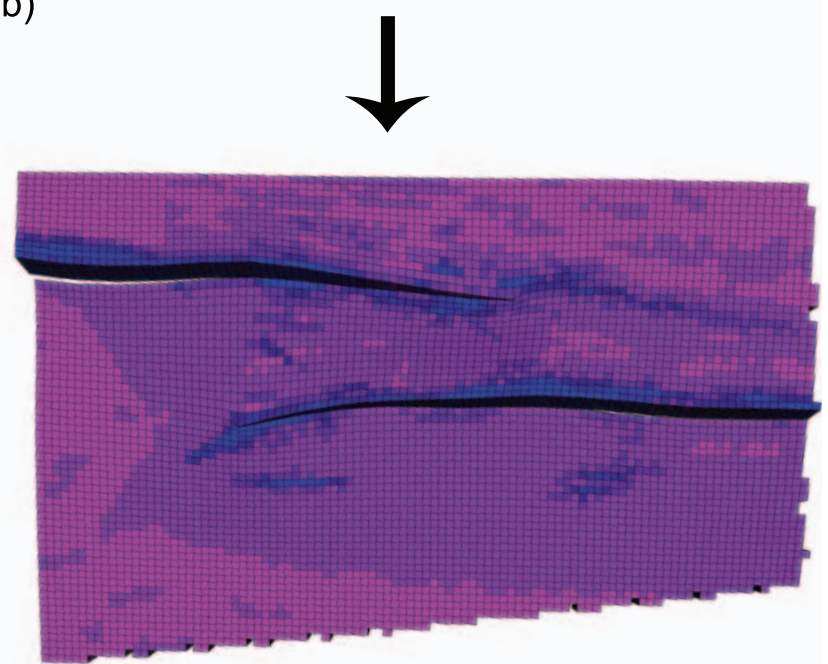

(c)

Fig. 4. Workflow showing the incorporation of mapped structures (a) in the geocellular model. The deformation band frequency map (a) was digitized and imported to the reservoir modelling software as a trend map (b). Subsequently, the trend map was used to populate a conditioning grid (c) that was used to condition cell permeabilities in the simulation models. See text for details. See Figure $2 b$ for legend and details of (a).

was generated based on scan lines in the y-direction (N-S). Comparison of the new x-direction (E-W) scan lines (Fig. 2c) and general field observations with the $y-(\mathrm{N}-\mathrm{S})$ scan lines show a relatively constant relationship between deformation band frequency in the $\mathrm{x}$ - and $\mathrm{y}$-directions on the chosen scale of resolution. The number of deformation bands crossed per metre in the $\mathrm{y}$ - and $\mathrm{x}$-directions displays a relationship $\mathrm{x}: \mathrm{y}=1$ : 5 in the lower four frequency contour intervals (Fig. 2b), whereas a relationship 1: 2 is observed in the highest frequency contour intervals (Fig. 2b). These relationships are used to 

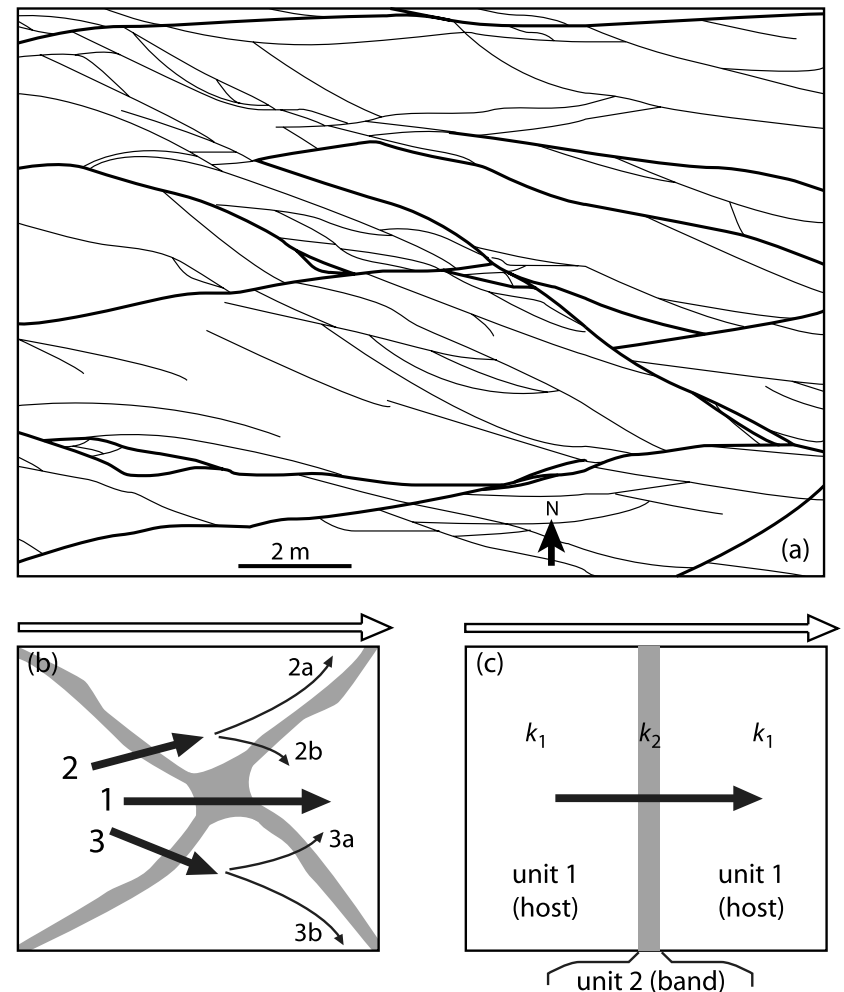

Fig. 5. (a) A $10 \times 14 \mathrm{~m}$ area of the western part of the ramp illustrates how the deformation bands of different orientations interact and compartmentalize the ramp. The thicker deformation bands are indicated with a thicker stroke. (b) Possible flow paths for a particle of fluid flowing from the left to the right in a grid cell where two deformation bands cross-cut one another, forming a micro-trap. (c) As a minimum approximation, we consider each micro-trap the equivalent of one individual deformation band, and apply the harmonic average to calculate the effective permeability for the situation in (b).

weight the impact of deformation bands on permeability in the $\mathrm{x}$ - and $\mathrm{y}$-directions. Essentially, permeability in the $\mathrm{x}$-direction is calculated using a fifth of the amount of deformation bands recorded in the y-direction, except in the higher frequency interval, where half as many deformation bands as the $\mathrm{y}$-direction are used.

The calculation of effective permeability (perm_x and perm_y) for each cell can be performed analytically (Muskat 1937; Manzocchi et al. 1998). If flow is perpendicular to a set of permeability barriers (here, deformation bands), effective permeability is the harmonic average permeability of the rock mass and, if parallel, the arithmetic average. In geometrically more complex situations, the effective permeability must lie between these values (Manzocchi et al. 1998). Given the orientation of deformation bands (Fig. 2b), the harmonic average can justifiably be used to compute perm_y. However, for perm_x, the issue is more complex. As the deformation bands frequently cross-cut and intersect to create compartments (Fig. 5a), the arithmetic average would grossly underestimate perm_x. Encountering such compartments, fluids are forced to cross one or more deformation bands. Figure $5 b$ shows an approximation of possible flow paths. Flow paths $2 \mathrm{a}$ and $3 \mathrm{~b}$ represent the least hindrance to flow and, from that, we deduce that the encounter of such a mini-trap represents a barrier at least equivalent to that represented by a single deformation band (Fig. 5c). This is a minimum, since cross-cutting deformation bands often display thickening near the intersection (Fossen et al. 2005). Therefore, perm_x must be much closer to the harmonic average permeability than the arithmetic average permeability. Hence, the harmonic average is used for both perm_x and perm_y and is given by Cardwell \& Parsons (1945):

$$
K_{\text {eff }}=\frac{L}{\sum_{i=1}^{n} \frac{l_{i}}{k_{i}}}
$$

where $L$ is the total length of the flow path (10 $\mathrm{m}$ for each cell), and $l_{i}$ the accumulated width of unit $i$ with bulk permeability $k_{i}$ (Fig. 5c).

Perm_x and perm_y represent the main variables, for which a series of cases have been calculated (Fig. 6 and Table 1). The cumulative thickness of deformation bands in each cell is given by the 3D trend parameter, which shows the number of deformation bands per metre in each cell. However, within each contour interval there is a range (e.g. 1-10 deformation bands per metre in the second-lowest interval, see Fig. 2b). Thus, three scenarios are calculated for each selected deformation band permeability value: a best-case scenario (the smallest number of bands per metre in each contour interval), a worst-case scenario (the largest number of bands per metre in each contour interval) and an intermediate scenario (the median number of bands per metre in each interval). See Figure 6 and Table 1 for an overview of the different cases. The permeability values used for deformation bands in the model set up reflect published figures, which state that permeability inside bands may be $0-6$ orders of magnitude lower than the matrix (e.g. Antonellini \& Aydin 1994; Fisher \& Knipe 2001; Shipton et al. 2002). We have selected values within this range and use matrix: band permeability contrasts of $10^{1}, 10^{3}$ and $10^{5}$ in our models (Table 1).

\section{Analytical determination of fault transmissibility}

As the effects of the relay and the associated damage zone are the main focus of this study, we aim to keep all other parameters constant for all model runs. Thus, we calculate a transmissibility multiplier for the main faults that is kept constant for all models in the relay grid as well as the single fault grid. In high-quality, high-resolution, geologically driven fault transmissibility models, fault transmissibility multipliers are designed to capture the effects of fault properties on flow between two grid cells. Fault transmissibility multipliers can be determined analytically based on explicit consideration of grid-cell and fault-rock properties (Manzocchi et al. 1999). The transmissibility multiplier $T$, calculated for the flow simulations, is defined as:

$$
T=\left[1+\frac{t_{\mathrm{f}}}{L}\left(\frac{k_{\mathrm{m}}-k_{\mathrm{f}}}{k_{\mathrm{f}}}\right)\right]^{-1}
$$

where $t_{\mathrm{f}}$ is fault thickness, $L$ is grid cell length, $k_{\mathrm{m}}$ is grid cell permeability and $k_{\mathrm{f}}$ is fault permeability (see Manzocchi et al. 1999 for the deduction of this equation). Based on this relationship, $T$ was calculated. The fault core along the main faults bounding the Delicate Arch Ramp is defined as $c .1 \mathrm{~m}$ (average) thick zone of $100+$ deformation bands in clusters and anastomosing networks, accompanied by several slip planes. The fault permeability was thus calculated using the harmonic average permeability (equation (1)) of a $1 \mathrm{~m}$ thick zone consisting of host rock, slip planes and deformation bands (Table 2). Using this as input in equation (2), a transmissibility multiplier of 0.1 was calculated and is used in all model runs (see Table 2 for details). 


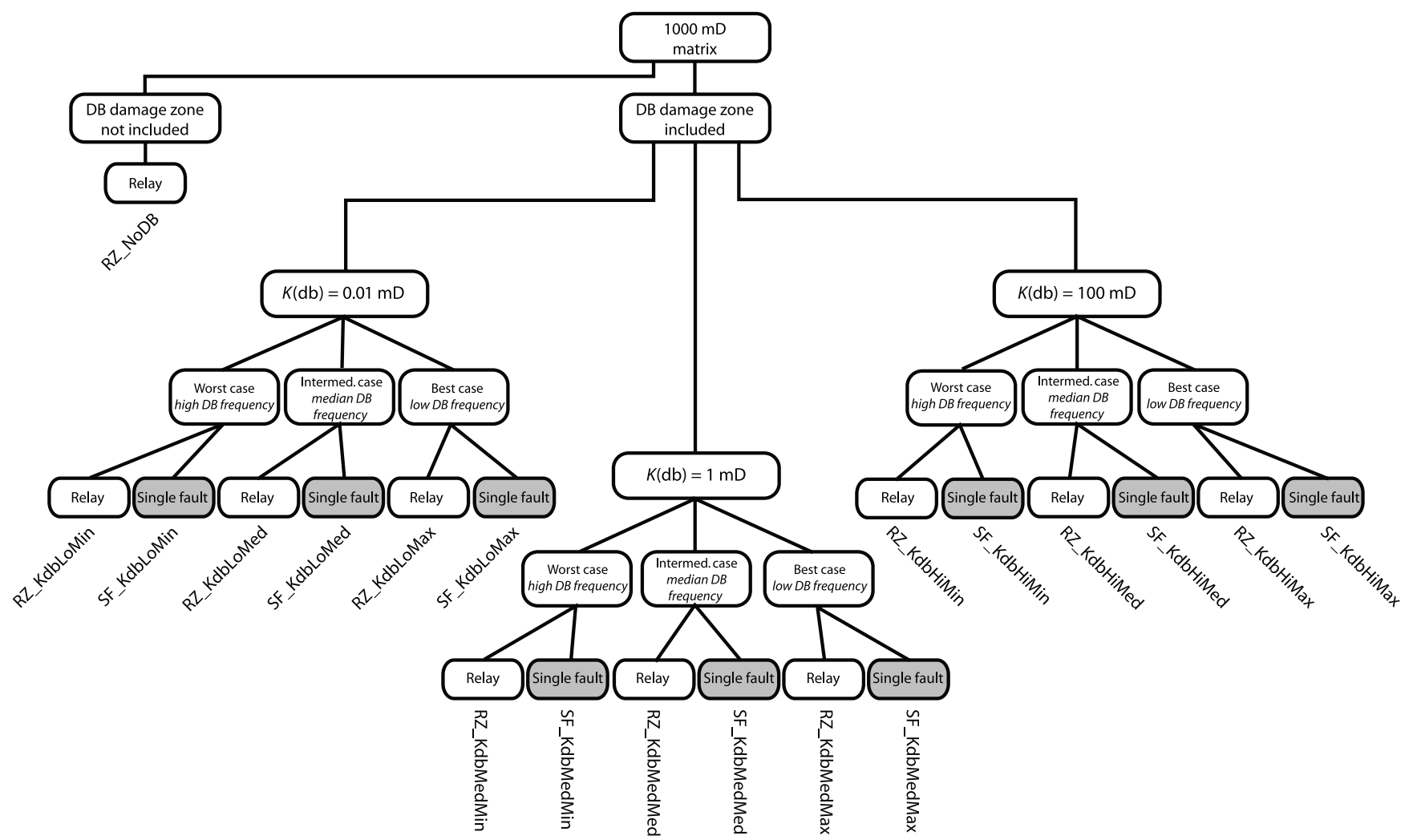

Fig. 6. Hierarchical overview of models built and simulated in this study. Note that the cases are all based on a matrix permeability of $1000 \mathrm{mD}$, but with variable deformation band frequency and -permeability. Thus, the cases are effectively different realizations of damage zone geometry and permeability.

Table 1. Models built and flow simulated in this study

\begin{tabular}{|c|c|c|c|c|c|c|}
\hline Model code & Grid & $\begin{array}{c}\text { Host per- } \\
\text { meability (mD) }\end{array}$ & $\begin{array}{l}\text { Deformation band } \\
\text { permeability }(\mathrm{mD})\end{array}$ & $\begin{array}{l}\text { Permeability contrast } \\
\text { host: def. band }\end{array}$ & $\begin{array}{l}\text { Best }(\max ) / \text { worst } \\
(\min ) \text { case indicator }\end{array}$ & $\begin{array}{l}\text { Transmissibility } \\
\text { multiplier }\end{array}$ \\
\hline \multicolumn{7}{|c|}{ Models with relay zone } \\
\hline RZ_KdbLoMed & relay & 1000 & 0.01 & 105 & med & 0.1 \\
\hline RZ_KdbLoMax & relay & 1000 & 0.01 & 105 & $\max$ & 0.1 \\
\hline RZ_KdbMedMin & relay & 1000 & 1 & 103 & $\min$ & 0.1 \\
\hline RZ_KdbMedMed & relay & 1000 & 1 & 103 & med & 0.1 \\
\hline RZ_KdbMedMax & relay & 1000 & 1 & 103 & $\max$ & 0.1 \\
\hline RZ_KdbHiMin & relay & 1000 & 100 & 101 & $\min$ & 0.1 \\
\hline RZ_KdbHiMed & relay & 1000 & 100 & 101 & med & 0.1 \\
\hline RZ_KdbHiMax & relay & 1000 & 100 & 101 & $\max$ & 0.1 \\
\hline RZ_NoDB & relay & 1000 & no bands & no bands & no bands & 0.1 \\
\hline \multicolumn{7}{|c|}{ Models with a single, through-going fault } \\
\hline SF_KdbLoMin & single through-going fault & 1000 & 0.01 & 105 & $\min$ & 0.1 \\
\hline SF_KdbLoMed & single through-going fault & 1000 & 0.01 & 105 & med & 0.1 \\
\hline SF_KdbLoMax & single through-going fault & 1000 & 0.01 & 105 & $\max$ & 0.1 \\
\hline SF_KdbMedMed & single through-going fault & 1000 & 1 & 103 & med & 0.1 \\
\hline SF_KdbMedMax & single through-going fault & 1000 & 1 & 103 & $\max$ & 0.1 \\
\hline SF_KdbHiMin & single through-going fault & 1000 & 100 & 101 & $\min$ & 0.1 \\
\hline SF_KdbHiMed & single through-going fault & 1000 & 100 & 101 & med & 0.1 \\
\hline SF_KdbHiMax & single through-going fault & 1000 & 100 & 101 & $\max$ & 0.1 \\
\hline
\end{tabular}

* Min, med and max being the worst, median and best cases, respectively, based on interval deformation band frequency (see text for details). The min cases are calculated based on the highest number of deformation bands per metre within each contour interval, whereas the max cases contain the least number of deformation bands per metre. The med cases are calculated based on the median of the former two.

\section{Properties in the single fault grid}

Identical matrix permeability $(1000 \mathrm{mD})$ and fault transmissibility (0.1) was used in the single fault grid. A realistic single-fault damage zone three grid cells wide on each side of the fault was created (Fig. 7). Values for deformation band occurrence near faults fall within the range of the uppermost three contour intervals (21-40, 41- 60 and 61-100) of Figure $2 \mathrm{~b}$ along the main faults. Thus, these three contour intervals are used to populate the single fault damage zone with deformation 
Table 2. Input parameters and analytical determination of fault permeability and fault transmissibility multipliers

\begin{tabular}{|c|c|c|c|}
\hline Parameter & Explanation & Value & Comments \\
\hline$t_{\mathrm{f}}$ & fault (core) thickness & $1 \mathrm{~m}$ & \\
\hline$L$ & grid cell length & $10 \mathrm{~m}$ & \\
\hline$k_{\mathrm{f}}$ & fault permeability & $0.161 \mathrm{mD}$ & derived from below \\
\hline$T$ & Fault transmissibility multiplier & 0.10 & calculated using equation (2) and figures herein \\
\hline \multicolumn{4}{|c|}{$\begin{array}{l}k_{\mathrm{f}} \text { above is the harmonic average permeability of the fault core based } \\
\text { on the following input: }\end{array}$} \\
\hline$l_{1}$ & accumulated thickness of 100 deformation bands & $0.2 \mathrm{~m}$ & \\
\hline$k_{1}$ & deformation band permeability & $1 \mathrm{mD}$ & the median of permeability values used in our models \\
\hline$l_{2}$ & accumulated thickness of three slip planes & $0.006 \mathrm{~m}$ & three slip planes are used \\
\hline $\mathrm{k}_{2}$ & slip plane permeability & $0.001 \mathrm{mD}$ & based on Antonellini \& Aydin (1994) \\
\hline $1_{3}$ & host-rock thickness $\left(L_{\text {tot }}\right.$ minus $l_{1}$ and $\left.l_{2}\right)$ & $0.794 \mathrm{~m}$ & \\
\hline $\mathrm{k}_{3}$ & host-rock permeability & $1000 \mathrm{mD}$ & the host-rock permeability used in all our models \\
\hline$L_{\text {tot }}$ & total thickness & $1 \mathrm{~m}$ & \\
\hline$k_{\mathrm{f}}$ & fault permeability & $0.161 \mathrm{mD}$ & calculated using equation (1) and figures herein \\
\hline
\end{tabular}

* Based on our contour map (Fig. 2b), the average values of deformation bands per metre in the grid cells adjacent to the main faults range mainly between 21 and 100 deformation bands per metre. Using the median of deformation band permeabilities used in the models (1 mD), this gives a grid cell harmonic average permeability of $15 \mathrm{mD}$. This value represents the average of several calculations using different numbers of bands per metre in the range $21-100$.
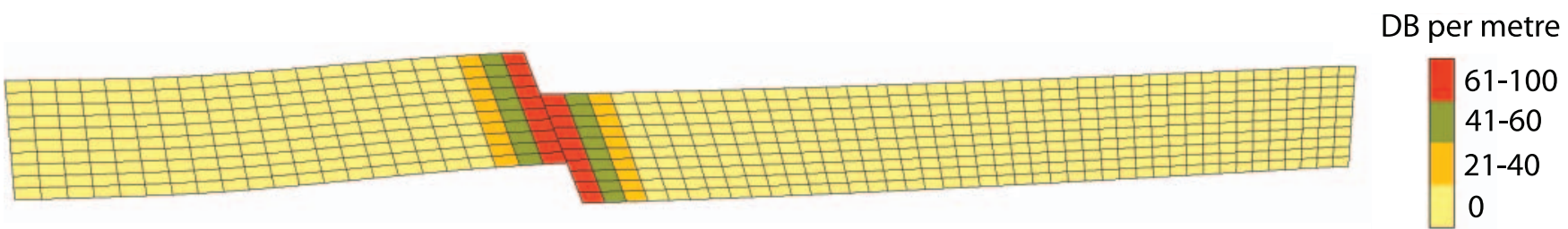

Fig. 7. Profile showing the geometry of the modelled damage zone in the single fault grid. The damage zone is defined to occupy three cell widths on each side of the fault and is populated with deformation bands according to the highest three contour intervals in Figure $2 \mathrm{~b}$, with progressively more intense deformation towards the fault plane. The legend refers to the number of deformation bands per metre in each cell (measured perpendicular to the fault).

band frequencies. Permeabilities were calculated in the same way as for the relay grid (see above). All simulation scenarios were run using both the relay grid and the single fault grid (Fig. 6).

\section{FLOW SIMULATION}

Flow simulation was performed using the RMS. finite difference, black oil simulator. The dynamic properties used to condition the models are summarized in Table 3. As the aim was to investigate the effects of the relay ramp and associated structural heterogeneity on fluid flow, typical mid-range properties were used and kept constant for all model runs. The flow simulations were based upon a single vertical water injection well and a single vertical production well placed on opposite sides of the relay system, $700 \mathrm{~m}$ apart. Identical well placements were used in the single fault grid. Flow rates of $500 \mathrm{Sm}^{3}$ per day were used for both injector and producer, and a fixed bottomhole pressure of 300 bars was set for the injector. Simulations were run until water breakthrough occurred in the producing well, but with an upward constraint of 50 years maximum simulation time. Some of the models had still not reached water breakthrough after 50 years.

The purpose of the exercise was to use flow simulation as a dynamic test of reservoir response to the presence of structural heterogeneity and perform a comparison of the different model scenarios. More sophisticated simulation approaches and optimization of the production are beyond the scope of this study.

\section{EXPERIMENTAL DESIGN}

A total of 19 models were built and flow simulated (Fig. 6 and Table 1). Simulation results were used to address two key questions.

1. How does the presence of a relay ramp affect production when compared to a simple fault zone (single, continuous fault)?

2. What effect does the presence of deformation bands associated with the relay ramp have on production?

Six key production parameters were used to analyse model sensitivity: oil saturation, reservoir pressure, total production, well production rate, recovery factor and time to water breakthrough. Results are presented graphically (Fig. 8, 9, 10 and 11) and in tabular form (Table 4).

\section{RESULTS AND INTERPRETATION}

The simulations results given in Figure 8 display a large spread of outcomes, with total produced oil volumes ranging from $0.66 \times 10^{6} \mathrm{Sm}^{3}$ to $1.72 \times 10^{6} \mathrm{Sm}^{3}$ and recovery factors ranging from $10 \%$ to $36 \%$ (see also Table 4). There is a significant difference between the STOIIP (stock tank oil initially in place, see Table 4) of the relay model and the single fault model $\left(3.8 \times 10^{6} \mathrm{Sm}^{3}\right.$ and $6.4 \times 10^{6} \mathrm{Sm}^{3}$, respectively). This is caused by contrasting depth distribution of the model volume with regard to the oil- water contact depth. Thus, the simulation results are best compared using the recovery factor, which is scaled to STOIIP. 
Table 3. Flow simulation dynamic properties

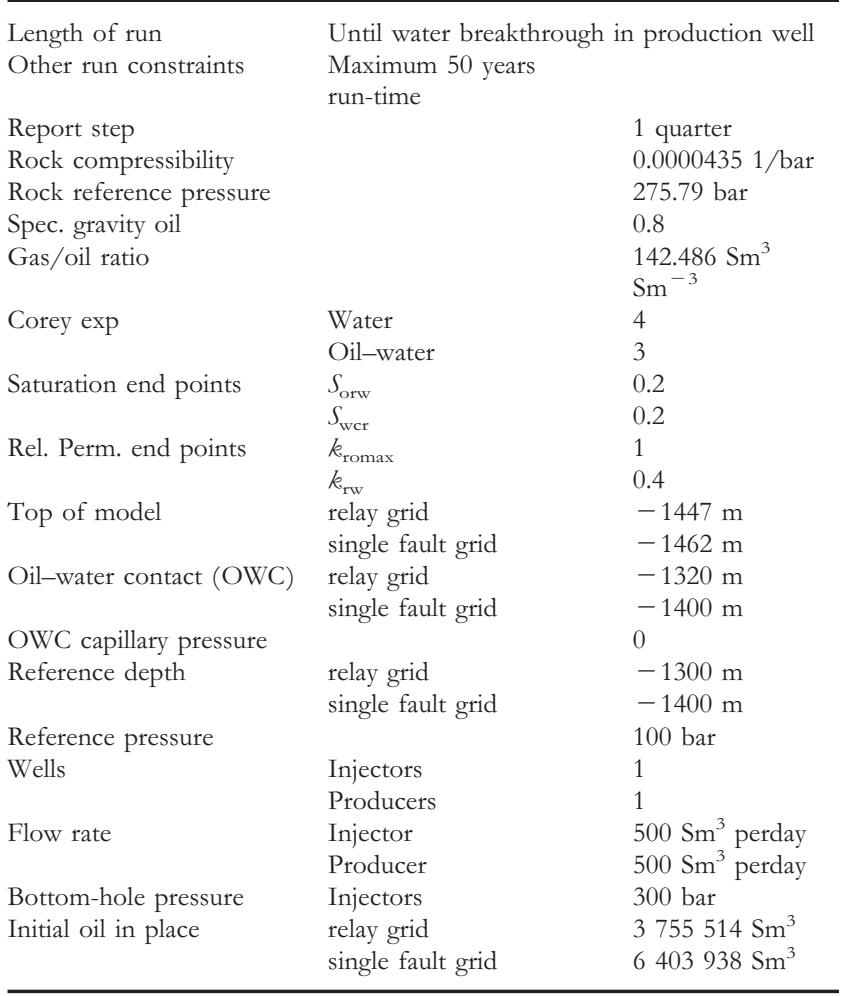

\section{Recovery vs. fault configuration}

Figure 9a shows the recovery factors for all cases, for both the single fault and relay ramp models. It is clear from these results that the relay ramp configuration achieves greater recovery factors. Given that all parameters are kept constant when simulating model pairs in the relay versus single fault scenarios, it must be concluded that relay ramps in all modelled cases yield a more efficient production than producing across a single, continuous low-permeable fault. However, the magnitude of the differences between relay models and single fault models varies. Plotting the difference in recovery factor for the various model pairs (Fig. 9b) shows that the difference in recovery (relay vs. single fault) is greatest in the cases with intermediate $K_{\mathrm{db}}\left(K_{\mathrm{db}}=\right.$ deformation band permeability $=1 \mathrm{mD}, 10^{3}$ matrix: band contrast), as well as the low $K_{\mathrm{db}}$ cases $\left(0.01 \mathrm{mD}, 10^{5}\right.$ matrix: band contrast) with intermediate and low deformation band frequencies. At high $K_{\mathrm{db}}\left(100 \mathrm{mD}, 10^{1}\right.$ matrix: band contrast), differences in recovery are negligible, probably due to the fact that the structural configuration has a smaller bearing on the result here, as fluids tend to flow across the faults rather than around them (Fig. 10e, k). The total recovered volumes (Fig. 8a and Table 4) are, however, greater in the single fault grid for these high $K_{\mathrm{db}}$ cases. This is because water breakthrough occurs much sooner in the relay models, leaving significant volumes of unswept oil, as shown in Figure 11 and Table 4.

The change of recovered volumes as $K_{\mathrm{db}}$ varies yields some interesting observations (Fig. 9a). Recoveries in the single fault cases are best for the high $K_{\mathrm{db}}$ scenarios. For the relay model, however, recovery increases as $K_{\mathrm{db}}$ is increased, but reaches a maximum in the intermediate $K_{\mathrm{db}}$ cases, before decreasing again for the high $K_{\mathrm{db}}$ cases. Thus, when compared to the relay case with no deformation bands (Fig. 9a), recovery is affected positively by the presence of deformation bands in the intermediate $K_{\mathrm{db}}$ cases. This may be because the bands increase tortuosity and delay water breakthrough (Fig. 11). Similar effects have been reported previously for discontinuous shale bodies (Jackson \& Muggeridge 2000).

When compared to the relay scenario with no deformation bands, the recovery factors of the other relay models are not affected negatively by the presence of deformation bands, except in the absolute worst-case scenario of the low $K_{\mathrm{db}}$ cases (RZ_KdbLoMin). This indicates that for deformation bands to have a negative effect on production in a relay setting, a significant number of extremely low-permeable deformation bands is needed.

\section{Effects of fault geometries and damage zone on fluid flow, tortuosity and sweep efficiency}

There are notable differences in the manner in which fluids flow from the injector toward the producing well between the relay and single fault models. The distribution of oil saturation at the end of each simulation for single fault models (Fig. 10) shows their dependence on damage zone properties, since all fluids flowing between the main compartments must cross the fault. In the cases with a low-permeable damage zone (Fig. 10a), the flow across the fault is minimal, as opposed to the observed cross-fault flow in Figures 10c and e. Interestingly, the water breakthrough occurs earliest in the intermediate-permeable cases (Fig. 10c, 11) in the single fault grid. This is probably due to an ideal combination of high pressure difference between the two compartments (Fig. 10d), and a sufficiently leaking fault system. In the highest-permeable cases (Fig. 10e), water breakthrough occurs later (Fig. 11), despite a more permeable fault system. This is probably due to the low pressure difference between the two compartments (Fig. 10f).

In the relay models, fluid flow between the main compartments occurs as a combination of cross-fault flow and tortuous around-fault flow (Fig. 10g, i, k). Whereas cross-fault flow is important in the high-permeable cases (Fig. 10k), tortuous around-fault flow dominates the low-permeable cases (Fig. $10 \mathrm{~g}$ ). The intermediate cases (Fig. 10i) feature a combination of both. Flow in the low-permeable cases (Fig. 10g) along the ramp follows certain relatively higher-permeable conduits. It is also evident that once past the tip point, fluids are still not flowing into the next compartment (Fig. 10g) due to the presence of the process zone of deformation bands in the continuation of the northern fault (Fig. 2b). This becomes even clearer when looking at the reservoir pressure (Fig. 10), which shows a pressure difference of c. 30-50 bars across the tip damage zone. In the intermediate cases (Fig. 10i), fluids flow more readily into the northern compartment, although there is a build up of fluids behind the process zone here also. In the high-permeable cases, the process zone does not affect flow, and fluid flow between the compartments largely occurs as cross-fault flow. Water breakthrough time occurs earliest in the high-permeable cases (Fig. 11) and progressively later in the intermediate- and low-permeable cases. In the low-permeable cases (Fig. 10g), water breakthrough does not occur within the 50 -year maximum simulation time (Fig. 11). This indicates that the low-permeable deformation bands in the damage zone exercise a strict control on fluid flow through the ramp, and the whole structure is very tight.

In the relay models, the sweep efficiency appears to be best in the intermediate-permeability cases (Fig. 10i). This is probably caused by the increased tortuosity due to the deformation bands in the damage zone, which forces injection fluids to places that would not be swept in a higher-permeable case. The low-permeable cases (Fig. 10g) are too impermeable to have 

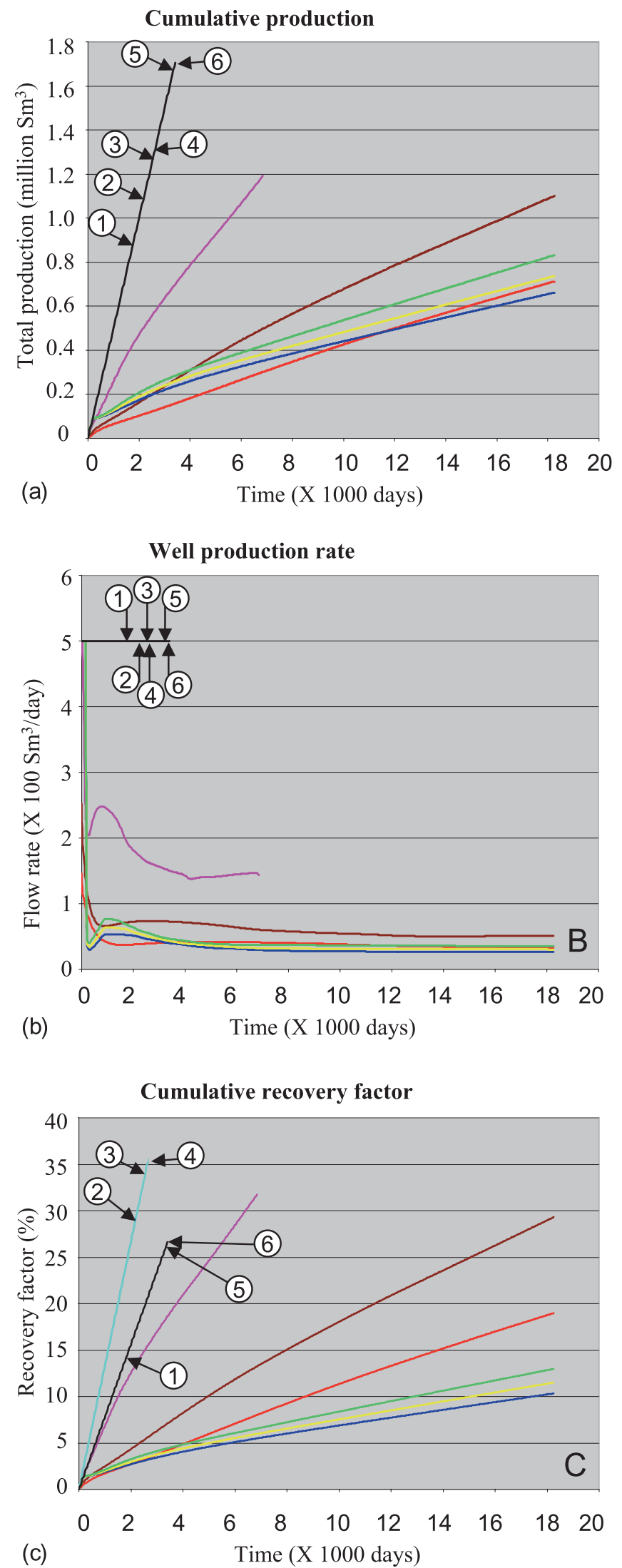

- RZ KdbLoMin

- RZ KdbLoMed

- RZ KdbLoMax

- SF KdbLoMin

- SF_KdbLoMed

- SF KdbLoMax

(1) - SF_KdbMedMin, SF_KdbMedMed, SF_KdbMedMax

(2) - RZ_KdbHiMin, RZ_KdbHiMed, RZ_KdbHiMax and RZ NoDB

(3) - RZ KdbMedMax

(4) - RZ_KdbMedMin, RZ_KdbMedMed

(5) - SF_KdbHiMin

6) - SF_KdbHiMed and SF_KdbHiMax

Only in the cumulative recovery plot (c):

(2) - RZ_KdbHiMin, RZ_KdbHiMed, RZ_KdbHiMax and RZ_NoDB

(3) - RZ_KdbMedMax

(4) - RZ_KdbMedMin, RZ_KdbMedMed

Fig. 8. Flow simulation results (see Figure 6 for an overview of the simulation case names). Numbers refer to simulation end-points for the respective simulations. (a) Cumulative production. Total oil volumes are used. (b) Well production rate through time. Total oil rates are used. (c) Cumulative recovery factor. The total production time varies as all models were run until water breakthrough occurred in the production well (see Table 4 for the water breakthrough time for each model). 


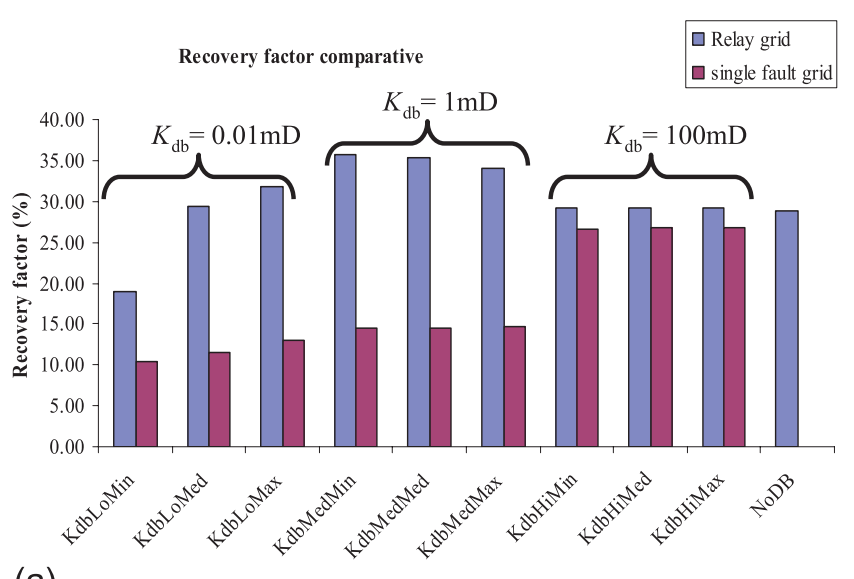

(a)

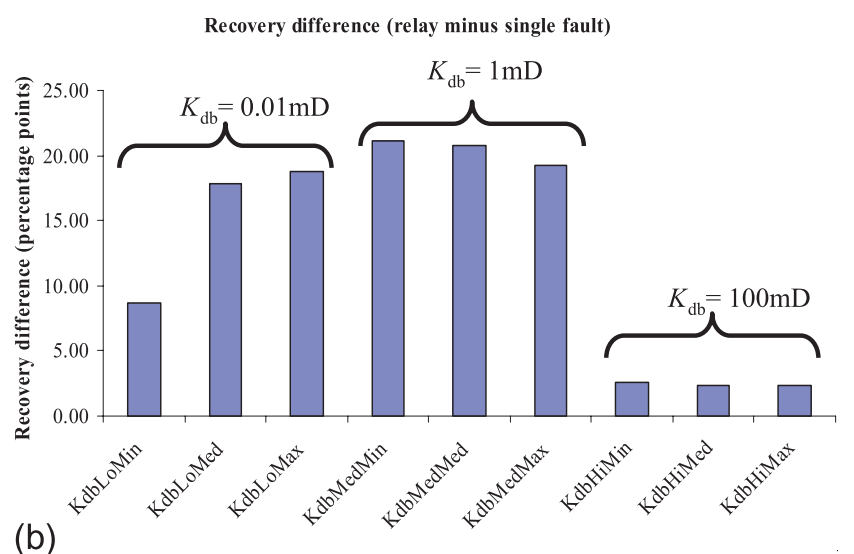

Fig. 9. Comparative production results. (a) Comparative recovery factor for relay vs. single fault grid for all flow simulated model pairs. (b) Recovery factor difference between relay and single fault models. Recovery factors of single fault models were subtracted from those of the equivalent relay models.

such an effect. This is also reflected by the higher recovery rates in the intermediate-permeable cases (Fig. 9a).

\section{Pressure and well production rates}

Well production rates (Fig. 8b) are important as they control the production total. As seen in Figure $8 \mathrm{a}-\mathrm{c}$, the intermediateand high- $K_{\mathrm{db}}$ cases have the same production rates, thus the differences in produced volumes are controlled by time to water breakthrough. This is because of the pressure support provided in these cases due to sufficient communication between the injection- and production wells. In low- $K_{\mathrm{db}}$ cases however, the deformation band damage zone permeability is too low to allow sufficient pressure support to maintain stable production rates, resulting in extreme pressure differences between the compartments (Fig. 10b, h) and low production rates. This is an important observation, as a complete lack of pressure communication makes the apparent geometric connectivity provided by the relay beds useless.

\section{CONCLUSIONS}

This study has demonstrated successfully that relay ramps represent conduits for fluid flow, which has been suggested previously by several authors (Peacock \& Sanderson 1991; Peacock \& Sanderson 1994; Trudgill \& Cartwright 1994; Childs et al. 1995; Cartwright et al. 1996; McGill et al. 2000; Imber et al. 2004; Hus et al. 2006, amongst others). Although some works exist that have documented fluid flow across relay ramps
(Bense \& Baalen 2004; Micarelli et al. 2006), the effects of fault damage in relay ramps has not been quantified to date in the existing literature. Our study shows that, for a range of damage zone permeability scenarios, relay ramps always provide a better pathway for flow than across a continuous low-permeable fault itself. This study, thus, yields a number of conclusions.

1. Relay ramps represent conduits for fluid flow.

2. The modelled relay ramp represents a better pathway for flow than across a continuous single fault in all simulated model pairs. We thus conclude that, for a given distribution of deformation bands and their related permeabilities, softlinked relay ramps represent a positive effect on the net flow across a fault system.

3. The damage zone, and the deformation bands within it, has significant impact on fluid flow as far as differences in time to water breakthrough, flow tortuosity and sweep efficiency are concerned.

4. Deformation bands must feature a high (more than three orders of magnitude) permeability contrast relative to matrix to significantly affect fluid flow. Limited or no effect of deformation bands is seen in the cases with one order of magnitude permeability contrast.

5. Deformation bands must be of extremely low-permeability (more than three orders of magnitude permeability contrast) and of great abundance to have a negative effect on recovery through the relay ramp.

6. Deformation bands may have a positive effect on recovery in intermediate-permeability cases by increasing tortuosity and delaying water breakthrough in the production well. They may also affect sweep efficiency positively, as injection fluids flow more tortuously and sweep areas that would not otherwise be swept.

7. In cases where relay damage zones consist of large amounts of very low-permeable deformation bands, pressure communication across the fault system may be extremely poor, despite the geometric connectivity of relay beds.

\section{Applicability}

The current study undertakes an examination of a relay ramp in mature, aeolian sandstones having undergone faulting at c. $2 \mathrm{~km}$ depth (Antonellini \& Aydin 1994; Davatzes \& Aydin 2003). In other areas, such as the Jurassic Brent reservoirs in the North Sea, faulting has occurred at near-surface depths. In such areas, cataclastic bands are rare, and the presence of low-permeable sub-seismic structures is, to a large extent, controlled by the mineralogical composition of the reservoir sand, which in turn is controlled chiefly by depositional facies and provenance. Pure sands develop disaggregation bands that have a modest effect on fluid flow. However, extremely low-permeability phyllosilicate bands have been reported in mica- and claybearing North Sea reservoir sandstones (e.g. Fisher \& Knipe 2001; Hesthammer \& Fossen 2001). Thus, ramps forming in poorly consolidated sandstones at shallow levels are likely to influence fluid flow in cases where continuous phyllosilicate bands are present. Microstructural and petrophysical examination of lithologies and deformation bands from cores is therefore essential in each case, regardless of depth of deformation.

Furthermore, the orientation of sub-seismic structures in the damage zone of relay ramps elsewhere may be different from those observed in this study. However, we believe that the general pattern is representative of relay ramps elsewhere, as similar patterns have been reported in relay ramps and fault intersections in other studies (Matthäi et al. 1998; Davatzes et al. 2005; Johansen et al. 2005; Ciftci \& Bozkurt 2006). This is 

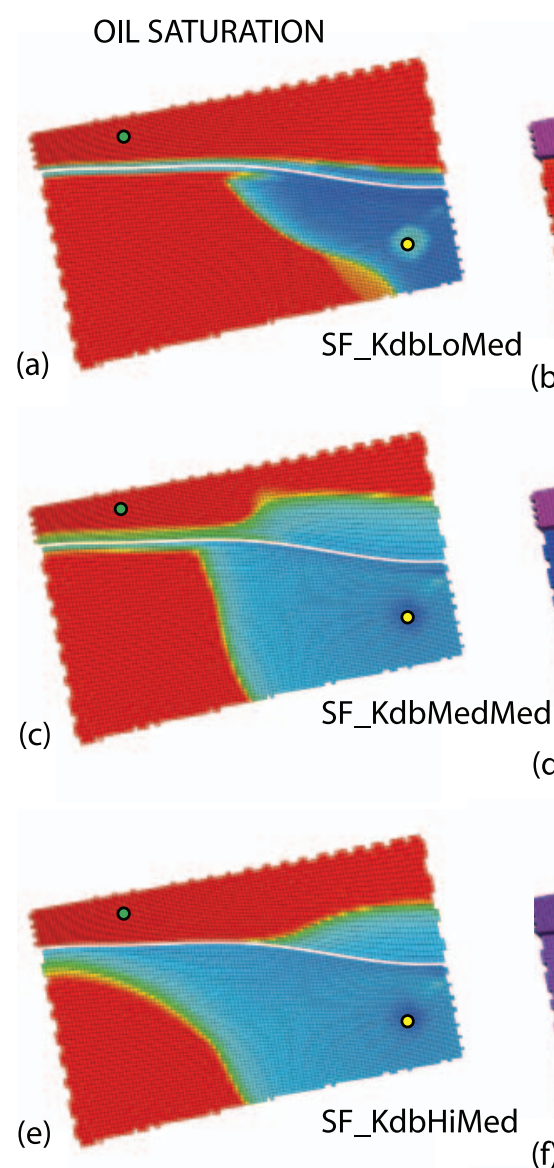

(e)

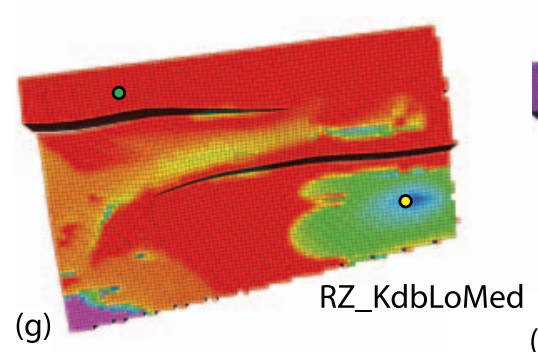

(g)

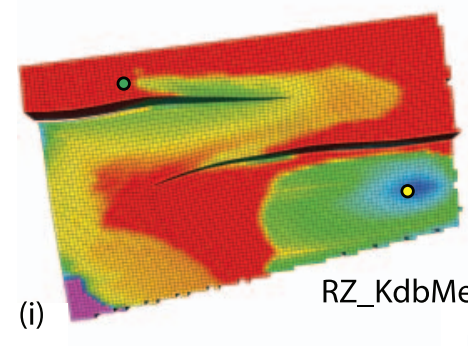

(i)

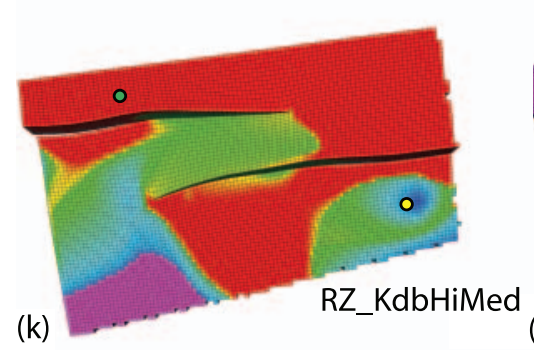

(d)

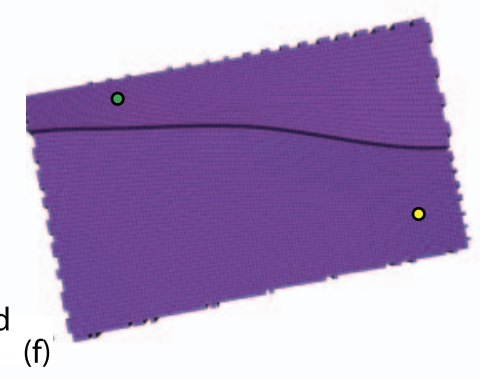

(h)

(b)
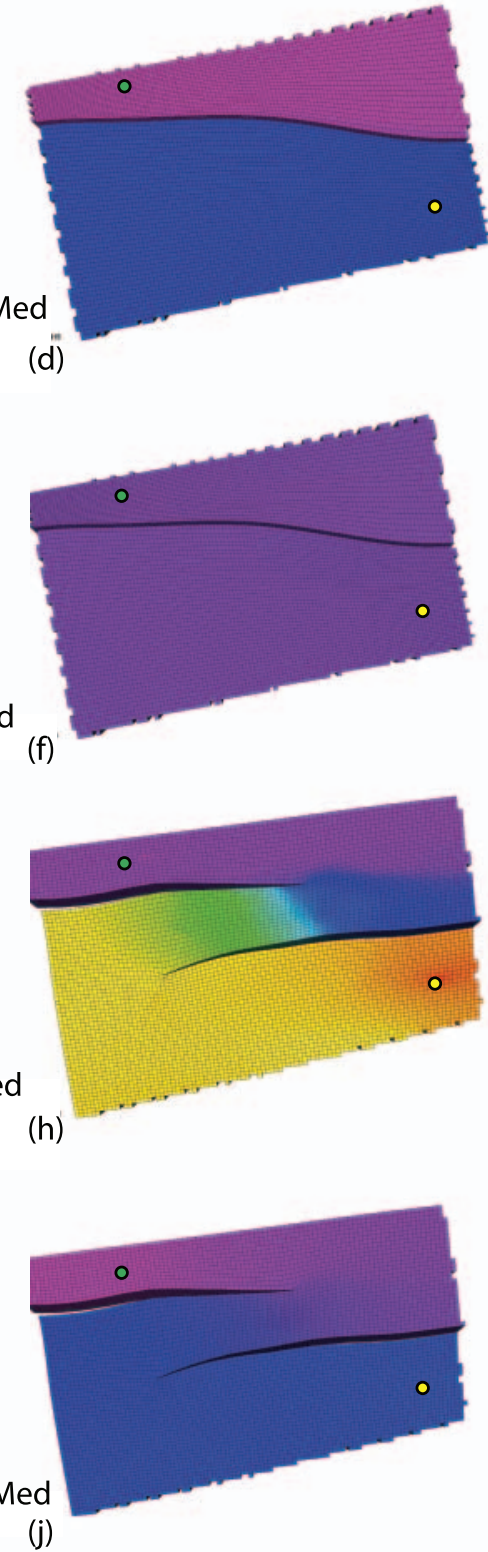

(j)

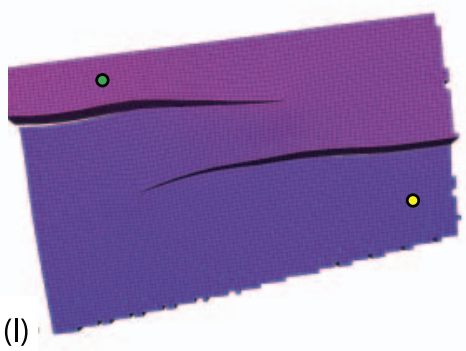

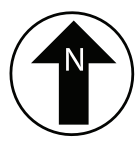

- Production well

- Injection well

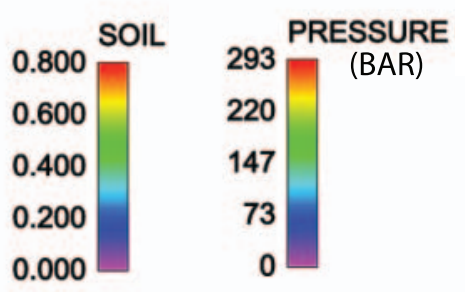

Relay ramp with no deformation bands: RZ_NoDB

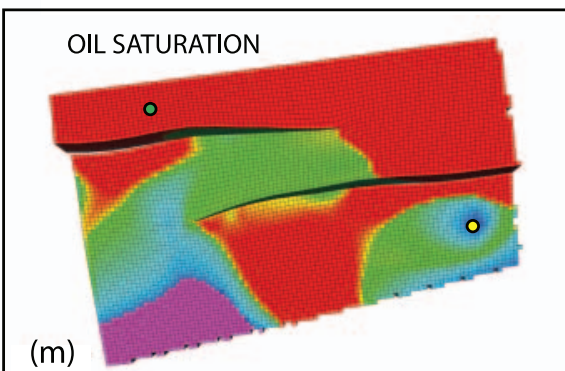

(n)

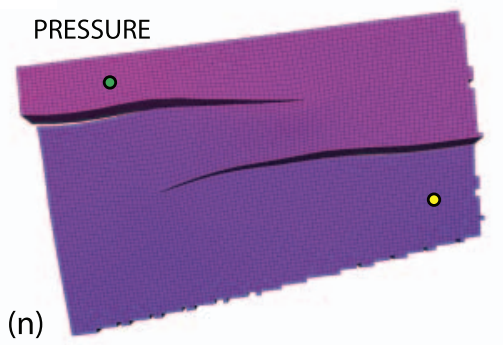

Fig. 10. Oil saturation and pressure at the end of simulation runs. Only the realizations using median deformation band frequency are shown $(\mathbf{a}-\mathbf{1})$. The reference case with no deformation bands is also shown $(\mathbf{m}, \mathbf{n})$. Locations of injection and production wells are indicated. SOIL, oil saturation. 
Table 4. Summary of flow simulation results

\begin{tabular}{|c|c|c|c|c|c|c|}
\hline Model code & $\begin{array}{c}\text { Def. band } \\
\text { permeability }(\mathrm{mD})\end{array}$ & $\begin{array}{c}\text { Frequency of } \\
\text { deformation bands* }\end{array}$ & STOIIP $\left(\mathrm{Sm}^{3}\right)$ & $\begin{array}{l}\text { Time to } \\
\text { WBTt(days) }\end{array}$ & $\begin{array}{l}\text { Total production at } \\
\text { WBT }+\left(\times 10^{6} \mathrm{Sm}_{3}\right.\end{array}$ & $\begin{array}{c}\text { Recovery factor at } \\
\text { WBT+ }(\%)\end{array}$ \\
\hline \multicolumn{7}{|c|}{ Models with relay zone } \\
\hline RZ_KdbLoMin $\ddagger$ & 0.01 & high & 3755514 & 18262 & 0.713 & 18.97 \\
\hline RZ_KdbLoMed & 0.01 & median & 3755514 & 18262 & 1.101 & 29.32 \\
\hline RZ_KdbLoMax & 0.01 & low & 3755514 & 6849 & 1.192 & 31.74 \\
\hline RZ_KdbMedMin & 1 & high & 3755514 & 2680 & 1.34 & 35.68 \\
\hline RZ_KdbMedMed & 1 & median & 3755514 & 2649 & 1.325 & 35.27 \\
\hline RZ_KdbHiMin & 100 & high & 3755514 & 2191 & 1.096 & 29.17 \\
\hline RZ_KdbHiMed & 100 & median & 3755514 & 2191 & 1.096 & 29.17 \\
\hline RZ_KdbHiMax & 100 & low & 3755514 & 2191 & 1.096 & 29.17 \\
\hline RZ_NoDB & no bands & none & 3755514 & 2161 & 1.081 & 28.77 \\
\hline \multicolumn{7}{|c|}{ Models with a single, through-going fault } \\
\hline SF_KdbLoMin $\ddagger$ & 0.01 & high & 6403938 & 18262 & 0.662 & 10.34 \\
\hline SF_KdbLoMed $\neq$ & 0.01 & median & 6403938 & 18262 & 0.737 & 11.51 \\
\hline SF_KdbLoMax $\ddagger$ & 0.01 & low & 6403938 & 18262 & 0.831 & 12.98 \\
\hline SF_KdbMedMed & 1 & median & 6403938 & 1857 & 0.929 & 14.50 \\
\hline SF_KdbMedMax & 1 & low & 6403938 & 1888 & 0.944 & 14.74 \\
\hline SF_KdbHiMin & 100 & high & 6403938 & 3410 & 1.705 & 26.62 \\
\hline SF_KdbHiMed & 100 & median & 6403938 & 3440 & 1.72 & 26.86 \\
\hline SF_KdbHiMax & 100 & low & 6403938 & 3440 & 1.72 & 26.86 \\
\hline
\end{tabular}

* The variance of deformation band frequency within each contour interval of the map in Figure $2 b$. See text for details on how this is captured in the cell permeability calculation.

${ }^{+}$WBT, Water breakthrough - the time at which the production well starts producing water.

* At time 18262 days (50 years), these models had still not reached water breakthrough.

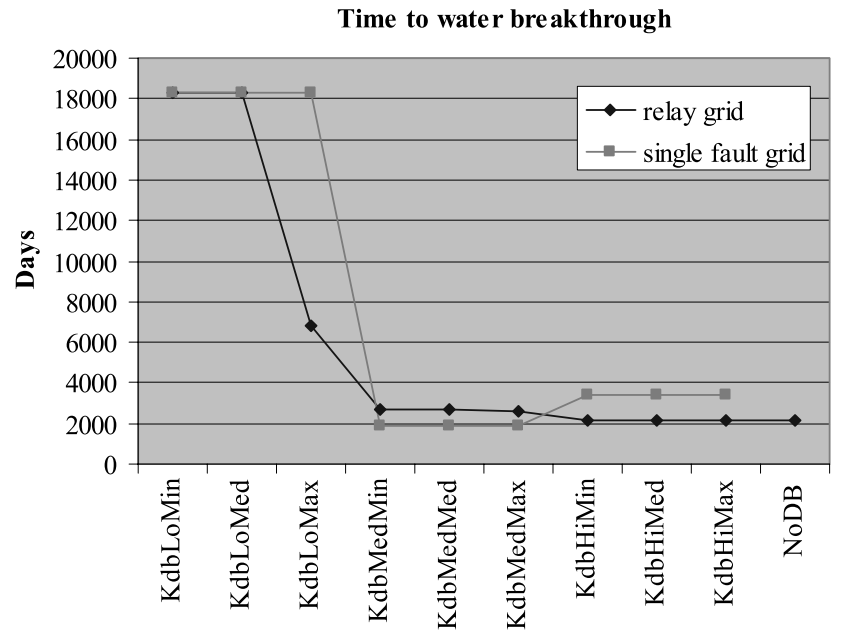

Fig. 11. Plot showing the time at which water breakthrough occurred in the production well in the different models. This is also the time at which simulations end.

supported further by the typicality of multiply orientated (sub-seismic) structures in regions of fault tip interaction (e.g. Kattenhorn et al. 2000; Maerten et al. 2002).

In summary, we suggest that, with caution and awareness of local factors, the mapped and flow-simulated example presented herein may be applied to relay ramps in siliciclastic reservoirs elsewhere.

\section{Future work}

The results of this study should be treated with some caution. It is a limitation of this study that deformation bands are not discretely represented in the flow simulations. If discrete deformation bands are included, a more detailed picture as far as flow tortuosity and sweep efficiency are concerned would probably emerge. Therefore, this is a desired subject for further modelling studies. However, we believe that our approach is successful in capturing most of these effects as the permeability of each cell is conditioned on the amount of deformation bands present as given by the mapping done at the Delicate Arch Ramp (Fig. 2b).

It should also be mentioned that in this study, a homogeneous 'sandbox' is used instead of real or synthetic realistic stratigraphy. In a real-world setting, stratigraphic layers less prone to forming low-permeable deformation bands could represent thief zones, where fluids bypass the deformation bands in other layers. Such an example would be the interdunes in the Delicate Arch Ramp, which could potentially provide a lower-permeable but less compartmentalized conduit for flow. This was, however, omitted from the modelling, for reasons of clarity with respect to the effects of damage zone features on fluid flow. Thus, the interplay between stratigraphy, overlapping faults and fluid flow is beyond the scope of this paper, and is discussed elsewhere (Rotevatn et al. 2009).

The authors wish to thank Tor Even Aas for assistance in the field. Elisabeth Dale and Sigurd Aanondsen are acknowledged for advice on dynamic input parameters used in the flow simulations. Two anonymous reviewers are thanked for helpful suggestions that contributed to improving the final version of this manuscript.

\section{REFERENCES}

Antonellini, M. \& Aydin, A. 1994. Effect of faulting on fluid flow in porous sandstones: petrophysical properties. American Association of Petroleum Geologists Bulletin, 78, 355-377.

Antonellini, M. \& Aydin, A. 1995. Effect of faulting on fluid flow in porous sandstones: geometry and spatial distribution. American Association of Petroleum Geologists Bulletin, 79, 642-671.

Antonellini, M., Aydin, A. \& Pollard, D.D. 1994. Microstructure of deformation bands in porous sandstones at Arches National Park, Utah. Journal of Structural Geology, 16, 941-959.

Aydin, A. 1978. Small faults formed as deformation bands in sandstone. Pageoph, 116, 913-930.

Aydin, A. \& Johnson, A.M. 1978. Development of faults as zones of deformation bands and as slip surfaces in sandstone. Pageoph, 116, 931-942. 
Aydin, A. \& Johnson, A.M. 1983. Analysis of faulting in porous sandstones. Journal of Structural Geology, 5, 19-31.

Bense, V.F. \& Baalen, R.V. 2004. The effect of fault relay and clay smearing on groundwater flowpatterns in the Lower Rhine Embayment. Basin Research, 16, 397-411.

Bense, V.F., Van Den Berg, E.H. \& Van Balen, R.T. 2003. Deformation mechanisms and hydraulic properties of fault zones in unconsolidated sediments; the Roer Valley Rift System, The Netherlands. Hydrogeology Journal, 11, 319-332.

Cardwell, W.T. \& Parsons, R.I. 1945. Average permeability of heterogeneous sands. Transactions of the American Institute of Mining Engineers, 160, 34-42.

Cartwright, J.A., Mansfield, C.S. \& Trudgill, B.D. 1996. Fault growth by segment linkage. In: Buchanan, P.C. \& Nieuwland, D.A. (eds) Modern Developments in Structural Interpretations. Geological Society, London, Special Publications, 99, 163-177.

Cashman, S. \& Cashman, K. 2000. Cataclasis and deformation-band formation in unconsolidated marine terrace sand, Humboldt County, California. Geology, 28, 111-114

Childs, C., Watterson, J. \& Walsh, J.J. 1995. Fault overlap zones within developing normal fault systems. Journal of the Geological Society, London, 152, $535-549$.

Ciftci, N.B. \& Bozkurt, E. 2006. Anomalous stress field and active breaching at relay ramps: a field example from Gediz Graben, SW Turkey. Geological Magazine, DOI:10.1017/S0016756807003500.

Cruikshank, K.M. \& Aydin, A. 1995. Unweaving the joints in Entrada Sandstone Arches National Park, Utah, U.S.A. Journal of Structural Geology', 17, 409-421.

Davatzes, N.C. \& Aydin, A. 2003. Overprinting faulting mechanisms in high porosity sandstones of SE Utah. Journal of Structural Geology, 25, 1795-1813.

Davatzes, N.C., Eichhubl, P. \& Aydin, A. 2005. Structural evolution of fault zones in sandstone by multiple deformation mechanisms: Moab fault, southeast Utah. Geological Society of America Bulletin, 117, 135-148.

Doelling, H.H. 2001. Geologic map of the Moab and eastern part of the San Rafael Desert 30' $\times 60^{\prime}$ quadrangles, Grand and Emery Counties, Utah, and Mesa County, Colorado. Utah Geological Survey, Map 180.

Du Bernard, X., Eichhubl, P. \& Aydin, A. 2002. Dilation bands: A new form of localized failure in granular media. Geophysical Research Letters, 29, 2176-2179.

Fisher, Q.J. \& Knipe, R.J. 2001. The permeability of faults within siliciclastic petroleum reservoirs of the North Sea and Norwegian Continental Shelf Marine and Petroleum Geology, 18, 1063-1081.

Fossen, H. \& Hesthammer, J. 1998. Deformation bands and their significance in porous sandstone reservoirs. First Break, 16, 21-25.

Fossen, H., Johansen, T.E.S., Hesthammer, J. \& Rotevatn, A. 2005. Fault interaction in porous sandstone and implications for reservoir management; examples from Southern Utah. American Association of Petroleum Geologists Bulletin, 89, 1593-1606.

Fossen, H., Schultz, R.A., Shipton, Z.K. \& Mair, K. 2007. Deformation bands in sandstone a review. Journal of the Geological Society, London, 164, 755-769.

Hesthammer, J. \& Fossen, H. 1997. Seismic attribute analysis in structural interpretation of the Gullfaks Field, northern North Sea. Petroleum Geoscience, 3, 13-26.

Hesthammer, J. \& Fossen, H. 2001. Structural core analysis from the Gullfaks area, northern North Sea. Marine and Petroleum Geology, 18, 411-439.

Hus, R., De Batist, M., Klerkx, J. \& Matton, C. 2006. Fault linkage in continental rifts: structure and evolution of a large relay ramp in Zavarotny; Lake Baikal (Russia). Journal of Structural Geology, 28, 1338-1351.

Imber, J., Tuckwell, G.W., Childs, C. et al. 2004. Three-dimensional distinct element modelling of relay growth and breaching along normal faults. Journal of Structural Geology, 26, 1897-1911.

Jackson, M.D. \& Muggeridge, A.H. 2000. Effect of discontinuous shales on reservoir performance during horizontal waterflooding. Society of Petroleum Engineers Journal, 5, 446-455.

Johansen, T.E.S., Fossen, H. \& Kluge, R. 2005. The impact of syn-faulting porosity reduction on damage zone architecture in porous sandstone: an outcrop example from the Moab Fault, Utah. Journal of Structural Geology, 27, 1469-1485.

Kattenhorn, S.A., Aydin, A. \& Pollard, D.D. 2000. Joints at high angles to normal fault strike: an explanation using 3-D numerical models of fault-perturbed stress fields. Journal of Structural Geology, 22, 1-23.

Kim, Y.-S., Peacock, D.C.P. \& Sanderson, D.J. 2004. Fault damage zones. Journal of Structural Geology, 26, 503-517.
Knipe, R.J. 1997. Juxtaposition and seal diagrams to help analyze fault seals in hydrocarbon reservoirs. American Association of Petroleum Geologists Bulletin, 81, 187-195.

Larsen, P.H. 1988. Relay structures in a lower Permian basement involved extension system, East Greenland. Journal of Structural Geology, 10, 3-8.

Lothe, A.E., Gabrielsen, R.H., Biørnevoll-Hagen, N. \& Larsen, B.T. 2002. An experimental study of the texture of deformation bands; effects on the porosity and permeability of sandstones. Petroleum Geoscience, 8, 195-207.

Maerten, L., Gillespie, P. \& Pollard, D.D. 2002. Effects of local stress perturbation on secondary fault development. Journal of Structural Geology, 24, 145-153.

Mair, K., Main, I. \& Elphick, S. 2000. Sequential growth of deformation bands in the laboratory. Journal of Structural Geology, 22, 25-42.

Mandl, G., Dejong, L.N.J. \& Maltha, A. 1977. Shear zones in granular material. Rock. Mechanics, 9, 95-144.

Manzocchi, T., Ringrose, P.S. \& Underhill, J.R. 1998. Flow through fault systems in high-porosity sandstones. In: Coward, M.P., Daltaban, T.S. \& Johnson, H. (eds) Structural Geology in Reservoir Characterization. Geological Society, London, Special Publications, 137, 65-82.

Manzocchi, T., Walsh, J.J., Nell, P. \& Yielding, G. 1999. Fault transmissibility multipliers for flow simulation models. Petroleum Geoscience, 5, 53-63.

Manzocchi, T., Heath, A.E., Walsh, J.J., Childs, C. \& Bailey, W.R. 2004. Faults in conventional flow models: an investigation of numerical and geological assumptions. Annex 8 of the Final Technical Report of the SAIGUP Project (EU Project number NNE5-200020095).

Matthäi, S.K., Aydin, A., Pollard, D.D. \& Roberts, S.G. 1998. Numerical simulation of departures from radial drawdown in a faulted sandstone reservoir with joints and deformation bands. In: Jones, G., Fisher, Q.J. \& Knipe, R.J. (eds) Faulting, Fault Sealing and Fluid Flow in Hydrocarbon Reservoirs. Geological Society London, Special Publications, 147, 157-191.

McGill, G.E., Schultz, R.A. \& Moore, J.M. 2000. Fault growth by segment linkage: an explanation for scatter in maximum displacement and trace length data from the Canyonlands grabens of SE Utah: Discussion. Journal of Structural Geology, 22, 135-140.

Micarelli, L., Moretti, I., Jaubert, M. \& Moulouel, H. 2006. Fracture analysis in the south-western Corinth rift (Greece) and implications on fault hydraulic behavior. Tectonophysics, 426, 31-59.

Mollema, P.M. \& Antonellini, M. 1996. Compaction bands: a structural analog for anti-mode I cracks in aeolian sandstone. Tectonophysics, 267, 209-228.

Muskat, M. 1937. International Series in Physics. In: The Flow of Homogeneous Fluids Through Porous Media. McGraw-Hill, New York.

Peacock, D.C.P. \& Sanderson, D.J. 1991. Displacements, segment linkage and relay ramps in normal fault zones. Journal of Structural Geology, 13 721-733.

Peacock, D.C.P. \& Sanderson, D.J. 1994. Geometry and development of relay ramps in normal fault systems. American Association of Petroleum Geologists Bulletin, 78, 147-165.

Rotevatn, A., Fossen, H., Hesthammer, J., Aas, T.E. \& Howell, J.A. 2007. Are relay ramps conduits for fluid flow? Structural analysis of a relay ramp in Arches National Park, Utah. In: Lonergan, L., Jolly, R.J.H., Sanderson, D.J. \& Rawnsley, K. (eds) Fractured Reservoirs. Geological Society, London, Special Publications, 270, 55-71.

Rotevatn, A., Buckley, S.J., Howell, J.A. \& Fossen, H. 2009. Overlapping faults and their effect on fluid flow in different reservoir types: using LIDAR data in outcrop modeling of structurally complex reservoir analogues. American Association of Petroleum Geologists Bulletin, 93(3), (in press).

Shipton, Z.K. \& Cowie, P.A. 2003. A conceptual model for the origin of fault damage zone structures in high-porosity sandstone. Journal of Structural Geology, 25, 333-344.

Shipton, Z.K., Evans, J.P., Robeson, K.R., Forster, C.B. \& Snelgrove, S. 2002. Structural heterogeneity and permeability in faulted aeolian sandstone: Implication for subsurface modeling of faults. American Association of Petroleum Geologists Bulletin, 86, 863-883.

Trudgill, B.D. \& Cartwright, J.A. 1994. Relay ramp forms and normal fault linkages, Canyonlands National Park, Utah. Geological Society of America Bulletin, 106, 1143-1157.

Underhill, J.R. \& Woodcock, N.H. 1987. Faulting mechanisms in high porosity sandstones; New Red Sandstone, Arran, Scotland. In: Jones, M.E. \& Preston, R.M.F. (eds) Deformation of Sediments and Sedimentary Rocks. Geological Society, London, Special Publications, 29, 91-105.

Walsh, J.J., Watterson, J., Heath, A.E. \& Childs, C. 1998. Representation and scaling of faults in fluid flow models. Petroleum Geoscience, 4, 241-251. 